\title{
Efecto de la Vacunación a IBR con Virus vivo y Muerto, Sobre la Tasas de Preñez en Novillas Holstein Mestizas
}

\author{
Castro Guamán W. E, \\ Ortiz Naveda N.R, \\ Carrasco R.,
}

Facultad de Ciencias Agropecuarias,

Escuela Superior Politécnica de Chimborazo, Sede Orellana, Ecuador

Doi:10.19044/esj.2019.v15n30p50 ～URL:http://dx.doi.org/10.19044/esj.2019.v15n30p50

\section{Resumen}

El presente trabajo investigativo se realizó para determinar si la vacunación con el herpes virus bovino tipo 1 (HVB-1) como profilaxis para la rinotraqueitis infecciosa bovina tiene efecto sobre las tasas de preñez en novillas Holstein mestizas en la región amazónica ecuatoriana. Se utilizaron 60 novillas repartidas en tres grupos de 20 animales cada uno: sin inmunógeno, vacuna a virus vivo y vacuna a virus muerto. Se realizó el diagnóstico de gestación (45 días pos inseminación) mediante ultrasonografía trans-rectal. Para el manejo del experimento todos los grupos fueron sometidos a un protocolo de sincronización con progestágenos y estradiol. Se observó diferencias estadísticas significativas en los porcentajes de preñez, siendo mayor en el tratamiento testigo $(29,9 \%)$ respectivamente seguido del tratamiento con virus vivo con $(19,5 \%)$ y el tratamiento con virus muerto con $(19,2 \%)$. donde hubo valores estadísticamente diferentes en los tres tratamientos en estudio. La inoculación con el herpes virus bovino tipo 1 tiene efectos sobre las tasas de preñez en novillas Holstein mestizas.

Palabras clave: Progesterona, IBR, Ecógrafo, Vacunas Vivos Y Muertos 


\title{
Effect of Vaccination on IBR with Live and Dead Viruses: The Pregnancy Rates in Mixed Holsten Heifers
}

\author{
Castro Guamán W. E, \\ Ortiz Naveda N.R, \\ Carrasco R.,
}

Facultad de Ciencias Agropecuarias,

Escuela Superior Politécnica de Chimborazo, Sede Orellana, Ecuador

\begin{abstract}
This paper focuses on determining whether vaccination with bovine herpes virus type 1 (BHV-1) as prophylaxis for infectious bovine rhinotracheitis has an effect on pregnancy rates in mixed Holstein heifers in the Ecuadorian Amazon Region. Sixty heifers divided into three groups of 20 animals each were used with no immunogen, live virus vaccine, and dead virus vaccine. The diagnosis of pregnancy was determined (45 days postdissemination) by transrectal ultrasonography. For the management of the experiment, all the groups were subjected to a protocol of synchronization with prosgestagens and estradiol. Significant statistical differences were observed in the percentages of pregnancy which was higher in the control treatment $(29.9 \%)$ respectively. This was followed by treatment with live virus (19.5\%) and treatment with dead virus (19.2\%). There were statistically different values in the three treatments under study. Inoculation with bovine herpes virus type 1 has effects on pregnancy rates in mixed Holstein heifers.
\end{abstract}

Keywords: Progesterone, IBR, ultrasound, Live virus vaccine, Dead virus vaccine

\section{Introduction}

La Rinotraqueitis Infecciosa Bovina (IBR), es una patología viral infectocontagiosa, el virus puede permanecer en estado latente dentro de los ganglios nerviosos y reactivarse por diversas situaciones que provoquen stress como el trasporte, parto y tratamientos con glucocorticoides ocasionando una reducción de la eficiencia reproductiva al producir abortos (Bowland \& Shewen, 2015), lesiones necróticas en estructuras foliculares, lúteales, muerte embrionaria, neonatal, pérdida de peso y disminución de la producción láctea 
(Etchegaray, 2009). En el contexto ganadero de nuestro país, la falta de programas de control y profilaxis para las enfermedades virales se convierte en un entorno predisponente para la incidencia y prevalencia de enfermedades como el IBR, ya que el herpes virus bovina es una enfermedad que ataca al tracto respiratorio caracterizada por rinitis, traqueítis y fiebre (Hernández, 2018), siendo el aborto la consecuencia directa más grave desde un punto de vista económico. También el VHB-1 produce vulvovaginitis pustular infecciosa, balanopostitis, conjuntivitis; ocasionalmente se le ha asociado con metritis, endometritis, mastitis, epididimitis, dermatitis, enteritis y encefalomielitis (Correa, 2007). Por la cual la presente investigación tiene como objetivo evaluar el efecto de la vacunación a IBR con virus vivo y muerto, sobre la tasa de preñez en novillas Holstein mestizas.

\section{Materiales y Métodos}

El trabajo se realizó en el Cantón Santa Clara Provincia de Pastaza en la Amazonia Ecuatoriana, se utilizaron 60 vaquillas Holstein mestizas, los animales estaban sexualmente maduros (chequeado a través de ecografía) y clínicamente sanos, con un peso mínimo de $350 \mathrm{Kg}$, en una edad entre 18 y 24 meses, que hayan vivido por lo menos un año en el trópico, con una condición corporal entre 2,75 y 3,5, además vacunados para fiebre aftosa, rabia y carbunco. Se conformaron tres grupos: sin vacunación grupo testigo (T) 20 vaquillas, vacunados con virus vivo (cattlemaster) (VV) 20 vaquillas vacunados con virus muerto (hiprabovis-4) (VM) 20 vaquillas. En esta etapa los animales fueron sometidos a un programa de sincronización, para que las vaquillas inicien de manera homogénea un nuevo ciclo estral, dentro del cual se puedo realizar el monitoreo respectivo. Para la sincronización se utilizó: Benzoato de estradiol en dosis de $0.5 \mathrm{cc}$ por animal, y un dispositivo intravaginal CIDR de liberación lenta de progesterona el día cero, siete días posteriores se realizó la aplicación de prostaglandina, retiro del implante de P4, inyección de estradiol dando inicio así a un nuevo ciclo estral, lo cual se estimó que la ovulación sea aproximadamente a las 60 horas pos tratamiento donde fueros inseminadasartificialmente con semen convencional cada uno de los grupos en estudio y de allí determinar los tiempos para los estudios posteriores para tasa de preñez. La aplicación de la vacuna se lo realizó 60 horas post tratamiento de sincronización e IATF, la profilaxis vacunal respectiva fue con el virus vivo y muerto, como se explicó anteriormente en el esquema del experimento. El diagnostico de gestación se realizó a los 45 días por ultrasonografía el mismo día a todos los grupos en estudio. Se utilizó un Diseño de Completamente al Azar (DCA), los resultados fueron sometidos a la prueba de homogeneidad, para cada variable estudiada se estimaron la media aritmética y el error estándar (EE). Se probó si existían diferencias significativas entre los genotipos mediante la aplicación de análisis de la 
variancia (ANOVA) a un criterio de clasificación y pruebas de comparaciones múltiples de Tukey-Kramer HSD $(\mathrm{p} \leq 0,05)$.

\section{Resultados y Discusión}

El Cuadro 1 muestra la existencia dediferencias significativas $(\mathrm{p}<0,05)$, del grupo testigo en referencia a los porcentajes de preñez con los tratamientos con virus vivo y virus muerto. Los resultados coinciden Geiser et al. (2002) en donde mostraron en seis novillas inoculadas en el celo con el virus de la rinotraqueitis bovina infecciosa, los cuales fueron bajos porcentajes de preñez y la progesterona estaba en niveles bajos. En este trabajo los valores encontrados fueron inferiores. Woodbine et al. (2009) realizó un trabajo en novillas que fueron inoculados intravenosamente con virus de la rinotraqueitis bovina infecciosa a los días 7,14, 21, y 28, y se sacrificaron 13 a 15 días después de la inoculación para luego examinar los tractos reproductivos para detectar cambios citopatológicos, virus y antígeno viral, en donde las novillas inoculadas en los días 7 y 14 presentaban ooforitis leve caracterizada por focos de necrosis y acumulación de células mononucleares en el cuerpo lúteo, estas novillas también tenían algunos folículos necróticos en al menos un ovario, las novillas inoculadas en los días 21 y 28 no presentaban lesiones del cuerpo lúteo pero los folículos necróticos eran numerosos en ambos ovarios, el antígeno viral se observó en todaslas lesiones ováricas y el virus infeccioso fue aislado de algunos de los tejidos afectados en útero de todas las novillas inoculadas a los 21 y 28 días.

Cuadro 1. Tasas de preñez en cada tratamiento en estudio

\begin{tabular}{|l|l|}
\hline \multicolumn{1}{|c|}{ TRATAMIENTOS } & TASAS DE PREÑEZ \% \\
\hline Testigo 1 (t) & $26,5 \pm 0,9 \mathrm{a}$ \\
\hline Virus vivo 2 (vv) & $19,5 \pm 1,0 \mathrm{~b}$ \\
\hline Virus muerto 3 (vm) & $19,2 \pm 0,9 \mathrm{~b}$ \\
\hline
\end{tabular}

\section{Conclusiones}

Se concluye que las vacunas profilácticas del IBR con virus vivo y muerto podrían afectar las características anatómicas y endocrinológicas del cuerpo lúteo y por ende su comportamiento reproductivo viéndose reflejado significativamente en las tasas de preñez obtenidos en la presente investigación.

\section{References:}

1. Allan, E. M., Wiseman, A., \& Gibbs, H. A. (s.f.). Pasteurella species isolated from the bovine respiratory tract and their antimicrobial sensitivity patterns. . Vet Rec, 117:629-631.

2. Biuk-Rudan, N. S. C. (2000). Prevalence of antibodies to ibr and bvd viruses in dairy cows with reproductive disorders. el sevier, 63-70. 
Recuperado el 24 de 02 de 2019, de https://www.ncbi.nlm.nih.gov/pubmed/10729010.

3. Barrera Calva1, E. \& Córdova Izquierdo, A. (2016). Diagnóstico de Rinotraqueítis Infecciosa Bovina mediante Inmunoperoxidasa. Revista Electrónica de Veterinaria REDVET, 2-6.

4. Baker, J. C., Ames, T. R., \& Markham, R. J. (2017). Seroepizootiologic study of bovine respiratory syncytial virus in a dairy herd. Am J Vet, 47: 240-245.

5. Bowland, S. L. \& Shewen, P. E. (2015). Bovine respiratory disease: comercial vaccines currently available in Canada. . Can Vet J , 41:3348.

6. Biuk Etchegaray, P.B. (2009). Rinotraqueitis infecciosa bovina. Monografías de medicina veterinaria, 1-9. Recuperado el 15 de 06 de 2019, http://www.fmvz.unam.mx/fmvz/cienciavet/revistas/CVvol1/CVv1c0

7. Geiser, V. I. M. (2002). The latency-related gene of bovine herpesvirus- 1 can inhibit the ability of bICP0 to actívate productive infection. Gen. Virol., 83:2965-2971.

8. Hernández, R. (2018). Frecuencia de aislamientos de Mannheimia haemolytica y Pasteurella multocida en becerras con signos clínicos de enfermedad respiratoria, en un complejo lechero del estado de Hidalgo, México. Vet Mexicana, 43 1-8.

9. Graham, D. A. (2013). Bovine herpes virus1(BoHV-1) in cattle-a review with emphasis on reproductive impacts and the emergence of infection in Ireland and the United Kingdom. Graham Irish Veterinary Journal, 66:15.

10. Mars, M. d. (2000). Airborne transmission of bovine herpesvirus 1 infections in calves under field conditions. Vet.Microbiol., 76, 1-13.

11. Perrin, B., Dannacher, G., \& Solsona, M. (2015). Mise en evidence des anticorpos contre le virus Respiratoire syncitial chez les bovins français. . Rec Med Vet, , 155: 465-471.

12. Raaperi, K. B. S. (2012). Association of herd BRSV and BHV-1 seroprevalence with respiratory disease and reproductive performance in adult dairy cattle. Vet Scand, 54:4.

13. Schreiber, P., Matheise, J. P., Dessy, F., \& Heimann, M. (2017). High mortality rate associated with bovine respiratory syncytial virus (BRSV) infection in Belgian White Blue calves previously vaccinated with an Inactivated BRSV vaccine. J Vet Med, 47: 535-550.

14. Woodbine, KA. M. G.V. (2009). A four-year longitudinal seroepidemiological study of bovine herpesvirus type-1 (BHV-1) in adult cattle in 107 unvaccinated herds in south west England. Vet Res,5:5. 
Recuperado el 12 de 05 de 2019, de https://www.ncbi.nlm.nih.gov/pubmed/19183476.

15. Yus, E., Eiras, C., San Juan, M. L., \& Arnaiz, I. (2016). Situación actual y programas de control y erradicación del IBR en España. Albéitar, 131: 4-6. 